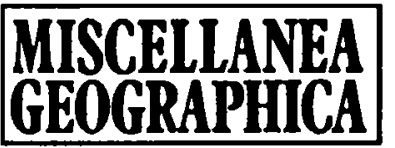

WARSZAWA 1996 VOI. 7

Elżbieta Wołk-Musial, Andrzej Musiał

\title{
THE NATURAL ENVIRONMENT OF WATERSHED DIVIDE ZONE OF THE VASSDALEN AND BERZELIUSDALEN VALLEYS (WEST SPITSBERGEN) BY USE OF TELEDETECTION
}

As part of preparations to the next Academic Polar Expedition named Spitsbergen '93 a preliminary analysis was performed of natural environment of the planned area of investigations, making use of panchromatic air photos. Previous studies of this type had so far been performed after termination of field work and after the return of expedition. The aim of the attempt presented herein was to facilitate the field works, carried out in very difficult conditions, and make them more efficient. In fact, they could be limited to checking the amount and quality of information obtained from interpretation of the photos taken of the area hitherto unknown by autopsy.

As the base for the present study served the panchromatic air photos taken by Norsk Polarinstitutt (scale 1:50,000) as well as the following maps (scale 1:100,000): the geological map of Van Mijenfjorden (Hjelle et al., 1986) and topographic map of B 10 Van Mijenfjorden (Norsk Polarinstitutt, 1982).

As a result of closed-circle interpretation of stereograms a Geomorphological Photointerpretation Scheme was worked out. Analysing graphic features of the area presented in air photos 10 units were distinguished, which were next subject to natural verification in field studies. Attention was focused first of all on the areas difficult for interpretation (snow cover or high phototonal and structural variability of the image in the zone of glacier ablation), aiming at full lithological and geomorphological recognition. Then the remaining units were examined in detail.

Closed-circle analysis of air photos has shown the presence of: slopes of different origin, the zone of occurrence of glacial cirques, valleys of different origin, structural edges, and in the apical zone - flatissements and areas difficult for interpretation

Next, as a result of field exploration and on the basis of preliminary photointerpretational recognition, natural environment was analysed, taking into account the lithology, relief, and climate of the area under investigation. Vassdalen and areas in its immediate vicinity lie on the west 


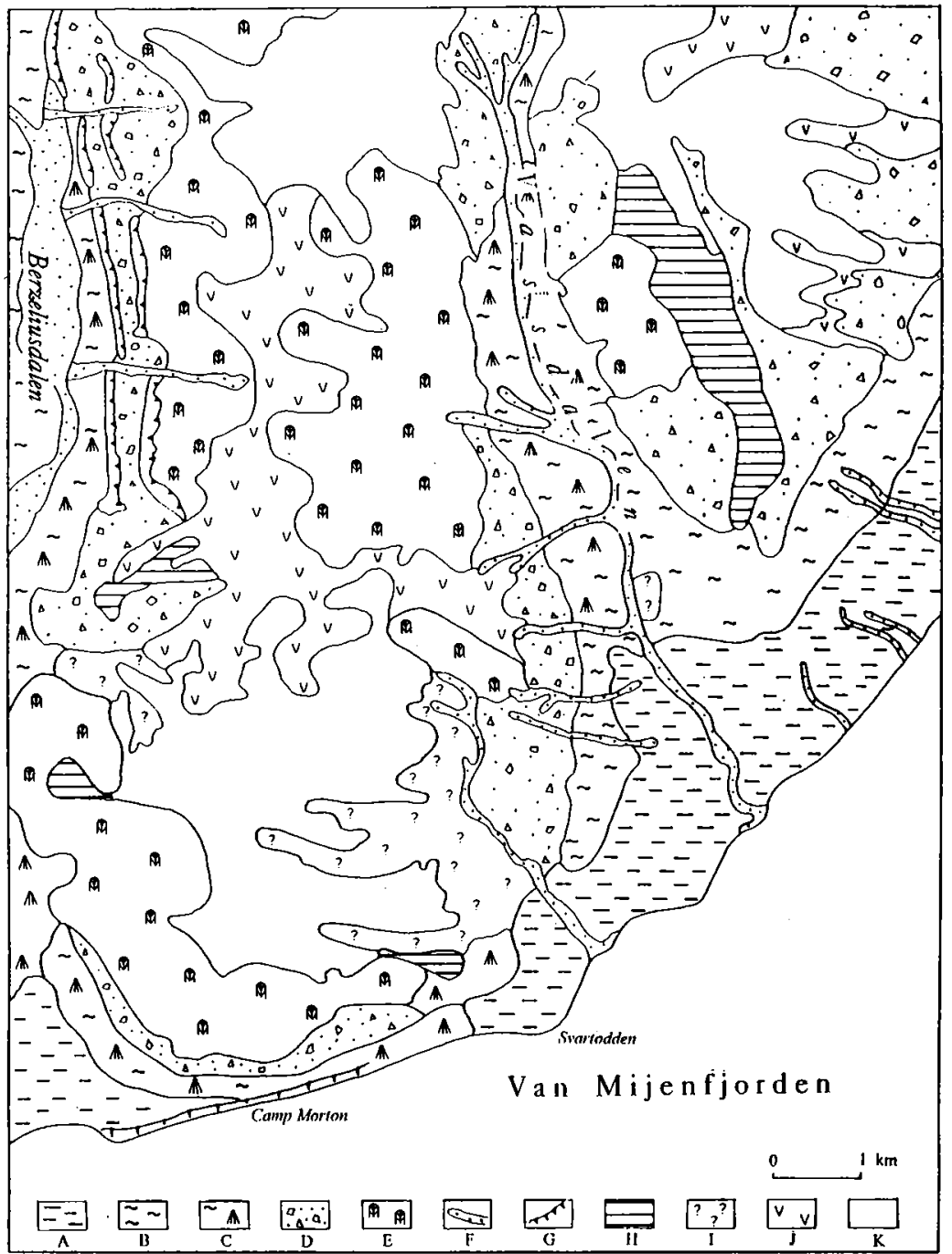

Fig. 1. Geomorphological photointerpretational schemes of watershed divide zone of the Vassdalen and Berzeliusdalen valleys

A. Mildly inclined slopes (light grey phototone, checked structure), B. Mildly inclined slopes with slope deposits (grey and dark grey phototone, fine linear structure), C. Slopes with different degrees of inclination with slope deposits and clear cone formations (grey phototone, geometric structure), D. Steep slopes with debris cover (phototone ranging from light grey to black, linear structure - snow-filled erosional furrows), E. The zone of occurrence of glacial cirques (grey phototone, concentric rib structure - valleys and gulches with snow), F. Valleys with clearly shaped bottom (light grey phototone, braid structure), G. Areas of structural bends and edges (white and light grey phototone, amorphic structure), H. Flatissements of surface cover (grey phototone, amorphic structure), I. Exposed areas (with no snow cover), difficult for interpretation (varying structure and texture), J. Areas in the surface zone, partly snow-covered - difficult for interpretation, $K$. Areas with compact snow cover (white phototone, amorphic structure) 


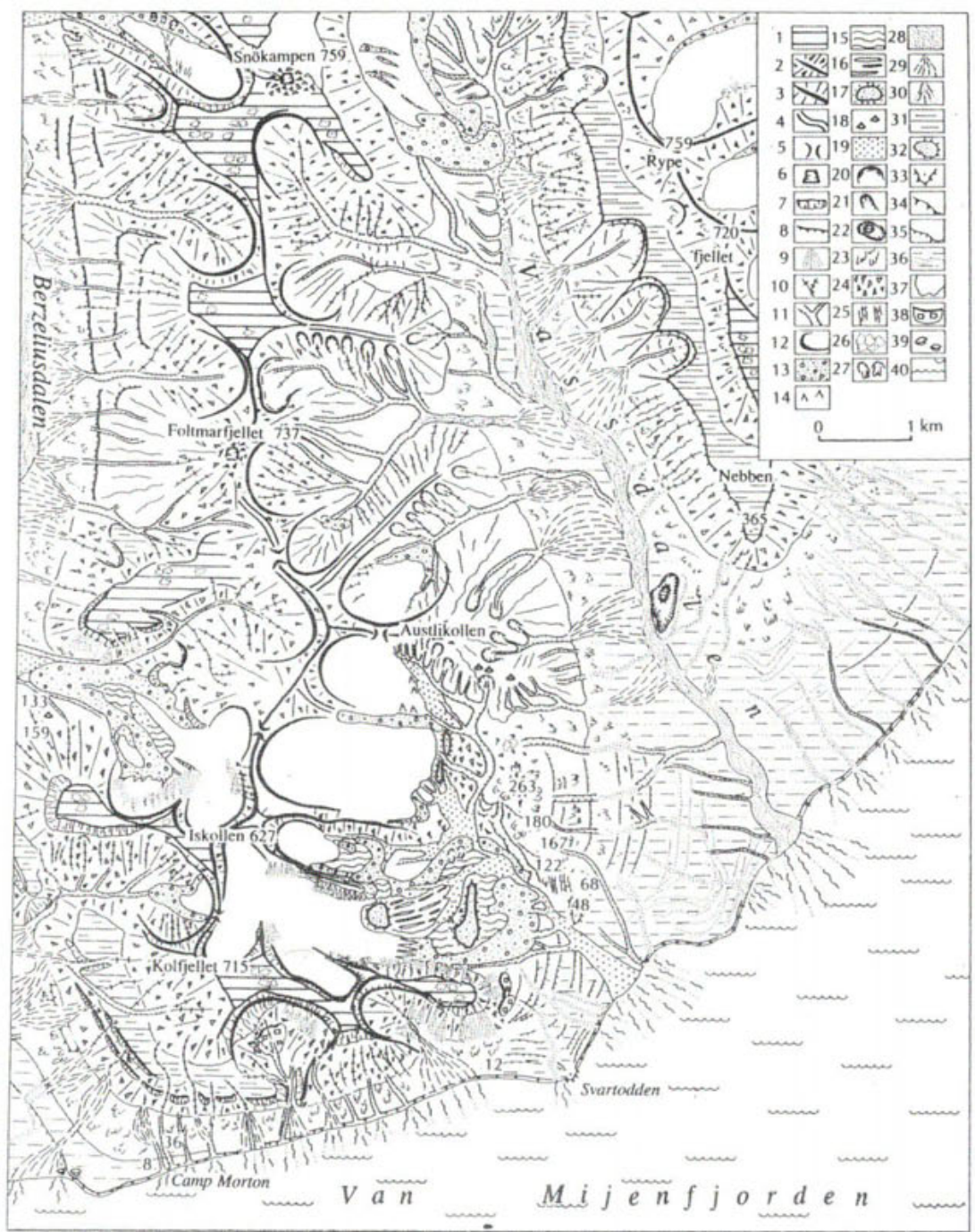

Fig. 2. Legend to geomorphological map of the area lying between Vassdalen and Berzeliusdalen

1. fragments of ancient field surfaces with covers of decomposed rock, 2. sharp mountain ridges with covers of debris and decomposed rock on the slopes, 3 . sharp mountain ridges with covers of shales and decomposed rock on the slopes, 4. rounded mountain ridges skeletonized in shales, 5. mountain passes, 4 . klippes, 7. rock walls, 8 . structural bends, 9 . talus cones, 10 . gulches, 11. deeply incised valleys and V-shaped valleys, 12 . glacial cirques, 13. ice-moraine ramparts: front, central, and lateral ones, 14. ice-moraine hills, 15. ground moraine, 16 . fluted moraine, 17. mutonized rock ridges under the cover of ground moraine, 18. erratics, 19 . sandras, 20 . nival cirques, 21. nival niches, 22. pingo hill with a small temporal lake, 23. solifluctional covers, 24. stone fields, 25. stone streaks, 26. structural soils, 27. landslide scars, 28. river-beds of glen rivers, 29. alluvial cones, 30. avantdeltas, 31 . flatissements of unknown origin, locally covered by slope deposits, 32. klippes of ancient sea terraces, 33. abrasional spurs, 34. the cliff, 35. edges of sea terraces, 36. sea terraces with ancient storm ramparts, 37. glaciers, 38. debris glaciers, 39. places of occurrence of fossil fauna, 40. fjord waters 
margin of tertiary tectonic basin, occupying the central part of West Spitsbergen. Tertiary rocks occur there: light-grey and green-grey sandstones, black shales, in some places with thin coal shears, and band clays (Hjelle et al. 1986).

Quaternary sediments occur in the form of glacial and glaciofluvial drifts, marine and glaciomarine formations, as well as slope and solifluctional ones.

In close vicinity of Camp Morton (Fig. 2) on terrace edges at the height of 2-8 $\mathrm{m}$ a.s.l. differently grained sands and marine silts with shells of $M y a$ truncata, Saxicava arctica and Saxicava rugosa are exposed. They are covered with coarse-clastic (glacio-marine) material which consists of weakly carved blocks of tertiary sandstones, $40-50 \mathrm{~cm}$ in size, single gravels and sharp-edged rock debris. These forms can be traced $1.5-2 \mathrm{~km}$ up the valley, because still higher they are hidden under vast alluvial cones.

Thermal conditions of the investigated area are given by the Norwegian station at Longyearbyen, situated $40 \mathrm{~km}$ away: the mean annual temperature is equal to $-6.1^{\circ} \mathrm{C}$, the temperature from March (the coldest month) is $-15.3^{\circ} \mathrm{C}$, and from July (the warmest month) is $+6.3^{\circ} \mathrm{C}$. The prevailing winds are from NE and $\mathrm{E}$, maximally exceeding $40 \mathrm{~m} / \mathrm{s}$. They cause local deflacions of the snow cover, which exerts some effect on the development of vegetation. In some places the deflated snow accumulates, which favours the development of processes of glaciation and nivation. The many years' snow-line in Nordenskiöld Land can be found at the height of $320-370 \mathrm{~m}$ a.s.l. During the summer the ground is defrosted to the depth of 0.9-1 m.

The vegetation period varies from 6 to 10 weeks. The vegetation consists mainly of tundra, the largest areas being covered by fresh grass tundra and lichen-mossy tundra. Locally one can encounter the lobes of dry mossy tundra, brushwood tundra, and snow patches.

Lithological differentiation of the area notably affects its relief. In places where black shales crop out the ridges are rounded, the slopes are milder, and the cirques are vast and shallow, with no sign of glaciers. The valleys are deeply incised, often in the form of $v$-shaped valleys. There are numerous nival niches which give the origin to erosional dissections and gulches. In the areas where shales are exposed the snow cover disappears much more rapidly and weathering wastes are easily and quickly dislocated. In places where sandstones are exposed, structural bend fronts, rock break, sharp mountain peaks, steep rock walls, klippes, etc. were formed. In relief of the area under examination there occur two valley systems running in the north-south direction, and divided by watershed divide zone. They are formed of fragments of ancient field surfaces, rising 650-600 m a.s.l., above which protrude the klippes of Snokampen (759 $\mathrm{m}$ a.s.l.) and Foltmarfjellet (737 $\mathrm{m}$ a.s.l.). The klippes are surrounded by stone fields.

Mountain ridges are almost completely covered by scarp, block-rubble, and locally clay-rubble cover. They form compact surfaces, cut by rock gulches, nival-corrasional and erosional dissections, where compact rock is exposed. 
The greatest diversity of glacial forms can be observed in the foreland of Kolfjell glacier which occupies the valley between mountain summits Iskollen $627 \mathrm{~m}$ a.s.l. and Kollfjellet $715 \mathrm{~m}$ a.s.l. The ice-moraine ramparts, delimiting its maximal extent, attain the relative height of a dozen or so meters, whereas their external slopes are inclined to the degree of $34^{\circ}$. Small-sized lichen thalli, i.a. of Rhizocarpon alpicola and Rhizocarpon geographicum occur only on the moraine material which is found here. This proves that the glacial relief is young (Karlen 1973). The melting ice is responsible for frequent occurrence of landfalls, muck tongues, and terraces. The ramparts cut the old glacier gates, which are suspended over valleys that once drained the melt waters. The upper part of one of such valleys is aggraded by an ice-moraine rampart, which may be the record of glacier transgression. The ground moraine is deposited on dead ice, and in some places it covers mutonized elevations of the rocky bed. A large area is occupied by the fluted moraine with huge boulders arranged in rows. As a result of advancing ablation, during the last 50 years the Kolfjell glacier has become shorter by some $1.8 \mathrm{~km}$.

The upper part of the Vassdalen valley is occupied by Vassdals glacier where the largest river of the area takes its beginning. A considerable inclination of its infraglacial area was favourable for the development of glacial erosion, as a result of which a large amount of rock material was dislocated. This process was facilitated by the type of bedrock, i.e. black shales. Under such conditions in the front zone particularly vast icemoraine ramparts were formed. The melt waters are drained through a system of deeply incised valleys.

Small cirque glaciers which occur on the northern side of the summits: Austlikollen $654 \mathrm{~m}$ a.s.l. and Kolfjellet $715 \mathrm{~m}$ a.s.l. are mostly covered by melted moraine. The ice-moraine ramparts which occur there are small. The debris glaciers, covered completely by sharp-edged material derived from rock walls, can be found not far from the shore of Van Mijenfjorden.

The lobes of many years' snow persist in some gulches, nival niches, the upper fragments of cirques, and on field surfaces.

On the slopes of mountain summits: Austlikollen from the side of the Vass valley and in the Berzelius valley, both built of black shales some flatissements occur. Also, erratics were found here: of granitoids, pink quartzitic sandstones, conglomerates, and sandstones. Some of them are formed of weathering-resistant rocks (granitoids and quartzitic sandstones) and occur in the form of boulders, the biggest of which was of the size $122 \times 10 \times 8 \mathrm{~cm}$. The remaining ones are of irregular shape, this being the result of weathering under polar conditions. On a pink granitoid the film of decomposed rock was $4.5 \mathrm{~mm}$ thick, other rock crumbled into pieces when picked up. The erratics were found on flatissements within Austlikollen area, about $300 \mathrm{~m}$ a.s.l., and on Hesselbergaksla: 133, 159, and $250 \mathrm{~m}$ a.s.l. 
The attempts at explaining the origin of erratic material and of the areas where these occur, are not yet unequivocal at the present stage of investigations (Musiał 1984, 1992). It remains an open question whether it was transported by glaciers, or by pack-ice. However, on the basis of hitherto-obtained information, the glacial origin of this material seems to be more probable.

The development of relief in the investigated area was notably affected by isostatic and tectonic movements which in turn resulted in certain disturbances in the system of flatissements in the valleys (Lindner et al. 1991, Landvik et al. 1987).

The Vass river has an asymmetric basin with predominance of righthand-side tributaries. Its bottom is slightly inclined, within the level ranging from 0 to $250 \mathrm{~m}$ a.s.l., and has been modelled by glacial, glaciofluvial and periglacial processes.

At a distance of about $6.5 \mathrm{~km}$ from the fjord shore the river forms the rapids, above which the dips within its bottom become increased.

The alluvial cones, accumulated by the tributaries of the main river, are responsible for pushing the river-bed alternately to one side or the other. In places where the tributaries occur opposite each other, the river-bed is narrowed. In the upper part, the waters are towered and there is higher accumulation of rubble as well as its selection. At low water level (at the end of August, in September and in winter) a considerable part of the river-bed is dried. In times of thaw the rivers carry a large amount of mineral material which is deposited in the fjord in the form of avantdeltas. Near the estuaries a clear turbidity of the water is observed.

In the Vass valley, close to the river-bed, there is a pingo hill of the open system, on the summit of which a small lake was formed. The water level in this lake varies considerably, being the highest during the thaw, and the lowest in winter.

An intensive development of the slope processes resulted in the formation of large solifluctional covers with stone streaks, tongues, garland solifluctional terraces, etc. They were formed at the base of most ridges, summits, and elevations. Their development and displacements depend among other things on the inclination of the area.

The field surfaces, flatissements, locally also terraces and valley bottoms are covered by structural soils (stone polygons and cell soils). In the discussed case they are formed from sharp-edged and coarse-grained material (tertiary sandstones) and clay decomposed rocks.

The levels of terraces with complexes of storm ramparts are the record of Holocene marine transgression. In the part of Van Mijenfjorden shore under examination such areas stretch on the height of 6-8 $\mathrm{m}$ a.s.l., 10-12 $\mathrm{m}$ a.s.l., $32 \mathrm{~m}$ a.s.l., $43 \mathrm{~m}$ a.s.l., $46 \mathrm{~m}$ a.s.l., $59 \mathrm{~m}$ a.s.l., and $65 \mathrm{~m}$ a.s.l. They enter the Vass valley to about $2 \mathrm{~km}$ inland. Further on they disappear, being covered by glaciofluvial, solifluctional and denudation deposits. Fragments of higher terrace levels at $76,84,89,97,106$ ?, 110, 115, 123?, 150, 
$180,192,201,212,225$, and $247 \mathrm{~m}$ a.s.l. which can be seen on the hill $263 \mathrm{~m}$ a.s.l. and near Camp Morton are probably of different origin (Salvigsen, Elgersma, Landvik 1991). A comparison of these surfaces with those occurring in the Berzelius valley shows a considerable similarity (Musiał 1992).

The flatissements on Kolfjellet at the height of 300-350 $\mathrm{m}$ a.s.l. and of Rypefjellet at the height of $400-450 \mathrm{~m}$ a.s.l. are difficult to explain (maybe they have structural foundations?)

A considerable part of the shore-line is occupied by the cliff which locally exceeds $6 \mathrm{~m}$. On rock promontories some abrasional spurs were formed. The applied method of investigation allowed us to perform a deeper analysis of natural environment of the polar zone. A full presentation of relief forms and geomorphological photointerpretational units is shown in Table 1. It can be seen from this table that areas difficult for interpretation occur mainly near the edge of glaciers where a large variety of glacial forms of different lithology and configuration can be found. In the mountainous area small forms of relief often remain in shade of the other forms, and hence are not observed on teledetection materials. The linear structures, often observed on air photos, are interpreted as being connected with the presence of deeply incised valleys and gulches which cut through structural bends and marine terraces.

Table 1

Photomorphic units and forms of relief for watershed divide zone of the Vassdalen and Berzeliusdalen valleys

\begin{tabular}{|c|rrrrrrrrr|}
\hline Photomorphic unit* & \multicolumn{10}{|c|}{ Forms of relief* } \\
\hline A & 28 & 34 & 35 & 36 & & & & & \\
B & 23 & 28 & & & & & & \\
C & 11 & 23 & 29 & 36 & & & & \\
D & 7 & 10 & 11 & 24 & & & & \\
E & 2 & 3 & 5 & 6 & 7 & 9 & 10 & 20 & \\
F & 11 & 28 & & & & & & & \\
G & 8 & 34 & & & & & & & \\
H & 1 & 26 & & & & & & & \\
I & 4 & 9 & 11 & 13 & 15 & 16 & 17 & 19 & 24 \\
J & 2 & 4 & 10 & 11 & 20 & 21 & 22 & & \\
K & 9 & 12 & 37 & 38 & & & & & \\
\hline
\end{tabular}

*) Denotations are the same as in legends to respective maps.

The fact that a large part of the area is melted, the lobes of many years' snow, patches, and in particular compact tundra vegetation all make the elements of natural environment presented on teledetection materials more difficult to interpret.

It is difficult to establish precisely the extent of glaciers whose marginal part is covered by moraine material. A similar situation exists as far as detection of dead ice is concerned. 
It is impossible to draw an unequivocal border between the snow and snow-covered glaciers.

It is also rather difficult to identify plant communities, because the species occurring in the area are very small in size.

On the other hand, the long-lasting snow cover is helpful, as it better exposes the linear forms, such as cliffs, terrace edges, structural bends, and the like.

The quality of panchromatic photos on which the snow-and ice- covered areas are in direct vicinity to tundra-covered ones, is relatively poor, due to large differences in light reflection coefficient.

While taking the photos, it was important to catch the correct moment of exposition, taking into account the specific lighting conditions and the polar day. This makes it possible to eliminate long shadows cast by mountain ridges and summits.

The application of air photos to the investigations into natural environment of polar areas is particularly useful in studies of relief, especially the glaciofluvial, glacial, and marine relief.

\section{REFERENCES}

Hjelle A., Lauritzen O., Salvigsen O., and Winsnes T.S., 1986, Geological map of Sualbard. $1: 100$ 000. sheet $10 \mathrm{G}$ Van Mijenfjorden. Norsk Polarinstitutt. Oslo.

Karle $\mathrm{W}$ W., 1973, Holocene glacier and climatic variations, Kebnekaise mountains, Swedish Lapland, Geografiska Annaler, vol. 55, ser. A.

Landvik J.Y., Mangerud J., and Salvigsen O., 1987, The Late Weichselian and Holocene shoreline displacement on the west-central coast of Svalbard, Polar Research 5, Oslo.

Lindner L., Marks L., Roszczynko W. and Semil J,. 1991, Age of raised marine beaches of northern Hornsund Region, South Spitsbergen, Polish Polar Research 12, vol. 2.

Musiał A., 1984, Ancient glaciations in the northwestern part of Nordendkiold Land and their extent in the light of characteristic occurence of erratics, Miscellanea Geographica UW, Warszawa.

Musial A. 1992, Morphology of the lower part of Berzeliusdalen (Nordenskiold Land), Wyprawy Geograficzne na Spitsbergen, UMCS, Lublin.

NORSK POLARINSTITUTT, 1982, Topografisk kart over Svalbard $1: 100$ 000, Blad $B 10$ Van Mijenfjorden, Oslo.

Salvigsen O., Elgersma A., Landvik J.Y., 1991, Radiocarbon dated raised beaches in Northwestern Wedel Jarlsberg Land, Spitsbergen, Svalbard. 